University of Nebraska - Lincoln

DigitalCommons@University of Nebraska - Lincoln

Publications, Agencies and Staff of the U.S.

Department of Commerce

U.S. Department of Commerce

2011

\title{
DISTRIBUTION AND ABUNDANCE OF STREAM FISHES IN RELATION TO BARRIERS: IMPLICATIONS FOR MONITORING STREAM RECOVERY AFTER BARRIER REMOVAL
}

C. Gardner

University of Maine

S. M. Coghlan Jr.

University of Maine, stephen.coghlan@umit.maine.edu

J. Zydlewski

US Geological Survey

R. Saunders

NOAA National Marine Fisheries Service

Follow this and additional works at: https://digitalcommons.unl.edu/usdeptcommercepub

Part of the Environmental Sciences Commons

Gardner, C.; Coghlan, S. M. Jr.; Zydlewski, J.; and Saunders, R., "DISTRIBUTION AND ABUNDANCE OF STREAM FISHES IN RELATION TO BARRIERS: IMPLICATIONS FOR MONITORING STREAM RECOVERY AFTER BARRIER REMOVAL" (2011). Publications, Agencies and Staff of the U.S. Department of Commerce. 268.

https://digitalcommons.unl.edu/usdeptcommercepub/268

This Article is brought to you for free and open access by the U.S. Department of Commerce at DigitalCommons@University of Nebraska - Lincoln. It has been accepted for inclusion in Publications, Agencies and Staff of the U.S. Department of Commerce by an authorized administrator of DigitalCommons@University of Nebraska - Lincoln. 


\title{
DISTRIBUTION AND ABUNDANCE OF STREAM FISHES IN RELATION TO BARRIERS: IMPLICATIONS FOR MONITORING STREAM RECOVERY AFTER BARRIER REMOVAL
}

\author{
C. GARDNER ${ }^{\mathrm{a}, \mathrm{b}}$, S. M. COGHLAN JR ${ }^{\mathrm{a} *}$, J. ZYDLEWSKI ${ }^{\mathrm{a}, \mathrm{b}}$ and R. SAUNDERS ${ }^{\mathrm{c}}$ \\ ${ }^{a}$ University of Maine, Department of Wildlife Ecology, Orono Maine, USA \\ ${ }^{\mathrm{b}}$ US Geological Survey, Maine Cooperative Fish and Wildlife Research Unit, Orono Maine, USA \\ ${ }^{\mathrm{c}}$ NOAA National Marine Fisheries Service, Orono Maine, USA
}

\begin{abstract}
Dams are ubiquitous in coastal regions and have altered stream habitats and the distribution and abundance of stream fishes in those habitats by disrupting hydrology, temperature regime and habitat connectivity. Dam removal is a common restoration tool, but often the response of the fish assemblage is not monitored rigorously. Sedgeunkedunk Stream, a small tributary to the Penobscot River (Maine, USA), has been the focus of a restoration effort that includes the removal of two low-head dams. In this study, we quantified fish assemblage metrics along a longitudinal gradient in Sedgeunkedunk Stream and also in a nearby reference stream. By establishing pre-removal baseline conditions and associated variability and the conditions and variability immediately following removal, we can characterize future changes in the system associated with dam removal. Over 2 years prior to dam removal, species richness and abundance in Sedgeunkedunk Stream were highest downstream of the lowest dam, lowest immediately upstream of that dam and intermediate farther upstream; patterns were similar in the reference stream. Although seasonal and annual variation in metrics within each site was substantial, the overall upstream-to-downstream pattern along the stream gradient was remarkably consistent prior to dam removal. Immediately after dam removal, we saw significant decreases in richness and abundance downstream of the former dam site and a corresponding increase in fish abundance upstream of the former dam site. No such changes occurred in reference sites. Our results show that by quantifying baseline conditions in a small stream before restoration, the effects of stream restoration efforts on fish assemblages can be monitored successfully. These data set the stage for the long-term assessment of Sedgeunkedunk Stream and provide a simple methodology for assessment in other restoration projects. Copyright @ 2011 John Wiley \& Sons, Ltd.
\end{abstract}

KEY WORDS: anadromous; assemblage; biomonitoring; connectivity; dam; restoration

Received 30 May 2011; Accepted 29 June 2011

\section{INTRODUCTION}

Since the arrival of European settlers on the east coast of North America, human population growth and development have led to myriad disturbances in most terrestrial and aquatic ecosystems (Ehrlich and Holden 1971; Vitousek et al., 1997). Of interest here is the construction and eventual removal of dams. For centuries, dams have been built to control flows, create water supplies and generate electricity in the coastal watersheds of New England and elsewhere (Benke 1990). Dams caused changes in hydrology, sediment loading, temperature regimes and connectivity within and among ecosystems (Koster et al., 2007; Ligon et al., 1995; Petts 1980) and often were associated with industrial pollution (Rounsefell and Stringer 1945). The physicochemical effects of dams on streams have been well documented (Graf 2003) as have their effects on charismatic anadromous

*Correspondence to: S. M. Coghlan Jr., Department of Wildlife Ecology, University of Maine, 5755 Nutting Hall, Room 240, Orono, Maine, USA.

E-mail: stephen.coghlan@umit.maine.edu fishes such as the Pacific (Oncorhynchus spp.) and Atlantic (Salmo salar) salmon (Montgomery 2003). However, the impacts of dams on resident stream fish assemblages generally have not been well characterized (Baldigo and Warren 2008; Quinn and Kwak 2003; but see Dodd et al., 2003) nor have the obverse effects of dam removal (Hart et al., 2002; but see Burroughs et al., 2010; Bushaw-Newton et al., 2002). Although there has been great recent emphasis on restoring stream ecosystems perturbed by dams, the degree to which these ecosystems are capable of returning to a 'preimpact' state is not known (Dufour and Piegay 2009).

Dams may impact the distribution and abundance of stream fishes by disrupting the natural hydrologic and thermal regimes and fragmenting the habitat (Hayes et al., 2008; Pringle 1997; Winston et al., 1991). Anadromous fishes suffer more obvious impacts from fragmentation of stream habitat (Benke 1990) than would freshwater residents, and these impacts are obvious worldwide (Limburg and Waldman 2009). Historically, many rivers and ponds in Maine harboured spawning runs of anadromous species 
such as Atlantic salmon, alewife (Alosa pseudoharengus), sea lamprey (Petromyzon marinus) and rainbow smelt (Osmerus mordax). These populations have suffered from the direct fragmentation of historic spawning and rearing habitats (Saunders et al., 2006), but we have little information on how this obvious decline in anadromous species affects resident stream fish assemblages (Kiffney et al., 2009). In the Pacific Northwest, anadromous Pacific salmon transport marine-derived nutrients and energy into otherwise oligotrophic freshwater ecosystems, leading to increased biomass and/or productivity of several trophic levels (Bilby et al. 1996; Brock et al., 2007; Wipfli et al., 1998, 2003). It is likely that anadromous fishes exerted similar effects in Atlantic coastal streams (Garman 1992; West et al., 2010), but as dams have severed this marine-freshwater connectivity, anadromous species have experienced worldwide decline (Limburg and Waldman 2009), and freshwater systems have become more oligotrophic (Stockner et al., 2000).

Habitat fragmentation can prevent resident fish species, which make relatively short movements compared with anadromous species, from accessing critical habitats (Porto et al., 1999; Schmetterling and Adams 2004), thus disrupting longitudinal flows in energy and nutrients (Hall 1972). In small, non-fragmented streams, abundance, richness and ultimately diversity of resident fishes increase along a headwaters-to-valley gradient (Danehy et al., 1998) because of predictable increases in the availability and diversity of habitats (Sheldon 1968), energy for production and consumption (Lotrich 1973) and the species pool of potential colonizers in nearby rivers (Smith and Kraft 2005). Seasonal variability in metrics may be driven by upstream or downstream migration of large numbers of stream fishes to spawning or rearing habitats (Hall 1972) or dramatic changes in discharge (Danehy et al., 1998). Local peaks in abundance and diversity can shift upstream and downstream over time in response to discharge and resultant velocity barriers to potential colonizers from downstream reaches (Grossman et al., 2010). Ultimately, stream discharge and other physicochemical conditions varying along the longitudinal gradient lead to patterns of energy and nutrient flow to which stream ecosystems respond dynamically (Benke et al., 1988; Vannote et al., 1980), although interruptions in the lotic continuum by naturally or artificially occurring barriers and impoundments evince marked changes in the stream biota (Jones 2010; Ward and Stanford 1983). In coastal streams, anadromous fish may penetrate relatively far into headwaters, and the subsidies of marine-derived nutrients and energy associated with these migrants provide another gradient to which resident fishes may respond (Flecker et al., 2010; Mitchell and Cunjak 2007). If the presence of a dam alters these natural gradients, then the structure and function of resident fish assemblages should shift as well. According to Morita and Yamamoto (2002), declines in abundance and extirpation of sensitive species upstream of dams are 'inevitable'.

Sedgeunkedunk Stream, a small tributary of the Penobscot River below head-of-tide (Figure 1), typifies small streams in Maine impacted by low-head dams. Runs of anadromous

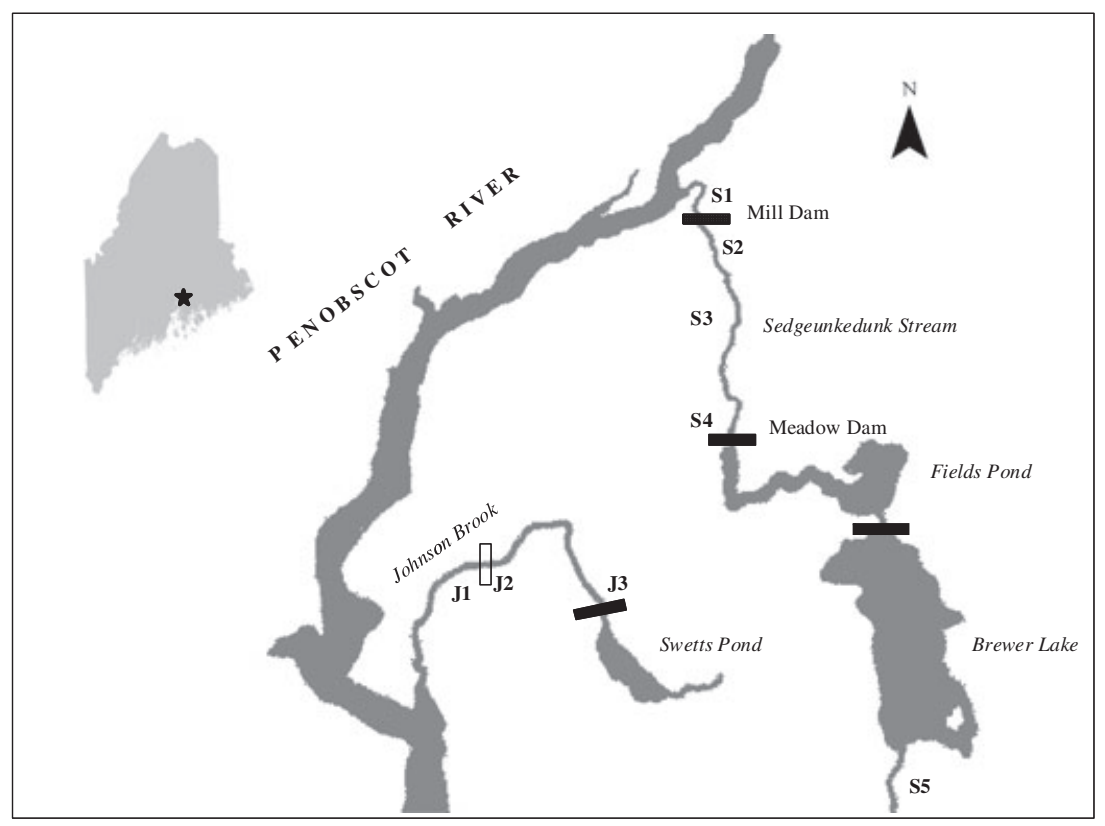

Figure 1. Study sites on Sedgeunkedunk Stream (S1-S5) and Johnson Brook (J1-J3), Penobscot Co., Maine, 2007-2009. Shaded rectangles indicate dam locations and open rectangles indicate falls 
fishes in Sedgeunkedunk Stream either have declined or disappeared after the building of multiple dams within the watershed. These declines mirror those in the entire Penobscot watershed, which contains over 100 known dams. Because Sedgeunkedunk Stream flows into the Penobscot River below the lowermost mainstem dam (Veazie Dam), it is one of only three major tributaries that could receive anadromous fishes before they encounter a relatively large, mainstem dam. Currently, Atlantic salmon in Sedgeunkedunk Stream and most of the Penobscot watershed is listed as a federally endangered species (74 Fed. Reg. 29344; 19 June 2009). Alewife, sea lamprey and rainbow smelt are at historic low levels of abundance in the Penobscot and throughout Maine (Saunders et al., 2006).

Current restoration efforts offer an opportunity to assess the structure and function of this fish assemblage when released from the chronic stressor of habitat fragmentation caused by multiple dams. As part of a collaborative restoration project, fish passage has been created or restored in Sedgeunkedunk Stream at the location of two dam sites between Fields Pond and the confluence with the Penobscot River (Figure 1). The lowermost dam (Mill Dam) was removed in August 2009, and the middle dam (Meadow Dam) was bypassed in August 2008 by a rock-ramp fishway that allows fish passage while maintaining current water levels in Fields Pond and adjacent wetlands. Thus, habitat connectivity for migrating anadromous and resident fishes has been restored throughout most of the Sedgeunkedunk watershed, although this remains to be explicitly demonstrated.

This study began in 2007, 2years prior to the removal of the lowermost dam, as the foundation for a long-term monitoring effort directed toward quantifying the effects of this restoration on assemblages of both resident and anadromous fishes. Although the reversion towards a more historic species composition is often the desired or expected outcome following dam removal, there is often an initial decline in abundance and diversity of resident species until the geomorphology of the stream is stabilized (Bushaw-Newton et al., 2002; Catalano et al., 2007; Doyle et al., 2005). In small streams, the physical recovery from the immediate disturbance of a dam removal can take as little as a year if high water events move the sediment from the impoundment downstream quickly (Burroughs et al., 2009; Bushaw-Newton et al., 2002). The response of the fish assemblages may be protracted (Hart et al., 2002), illustrating the importance of long-term monitoring to characterize biotic response. Many small streams are characterized by a great deal of variability at different scales, both spatially (longitudinally and within short reaches) and temporally (seasonally and annually; Danehy et al., 1998; Resh et al., 1988). This variability could make the detection of biologically meaningful changes in fish assemblages caused by perturbations such as dam removal difficult (Baldigo and
Warren 2008; Jackson et al., 2001). In this study, the data collected before the removals were used to quantify the baseline conditions and variability in this altered system, and in a neighbouring reference system, in anticipation of recovery over a longer time scale. Similar data were collected immediately following the removals.

Specifically, our objectives were to (i) quantify the baseline distribution and abundance, and the associated variability, of fish species in Sedgeunkedunk Stream before the final dam removal; (ii) quantify the distribution and abundance of fish species in Sedgeunkedunk Stream immediately following the removal of the lowermost dam; and (iii) determine if the temporal and spatial variability in fish assemblage metrics will allow us to detect changes in response to dam removals. This work represents the first step in assessing the long-term research goal of characterizing resilience and recovery in small coastal systems impacted by dams.

\section{MATERIALS AND METHODS}

\section{Study areas}

Sedgeunkedunk Stream is a third-order tributary of the Penobscot River, Penobscot Co., Maine. The stream flows out of Fields Pond at $44^{\circ} 44^{\prime} 05^{\prime \prime} \mathrm{N}$ and $68^{\circ} 45^{\prime} 56^{\prime \prime} \mathrm{W}$ and debouches into the Penobscot River (at river km 36, which is approximately at head-of-tide) at $44^{\circ} 46^{\prime} 08^{\prime \prime} \mathrm{N}$ and $68^{\circ} 47^{\prime}$ $06^{\prime \prime} \mathrm{W}$. The stream drains 5400ha including Brewer Lake and Fields Pond (Figure 1). The lowermost Mill Dam, which was removed in August 2009, was $3 \mathrm{~m}$ high and located just $610 \mathrm{~m}$ upstream of the stream's confluence with the Penobscot River. Historically, a dam has been present in one form or another at this site for more than 200years (Steve Shepard, Aquatic Systems Associates Brewer, ME, personal communication). The middle Meadow Dam, which was $2 \mathrm{~m}$ high and located at stream $\mathrm{km} 5.3$ (upstream from the Penobscot confluence), was replaced by a rock-ramp fishway in August 2008. The removal of these two barriers provides for presumably unimpeded access from the Atlantic Ocean into Fields Pond via the lower Penobscot River and then Sedgeunkedunk Stream. For the purposes of this study, we focus on the removal of Mill Dam and are not concerned with the effects of construction of the Meadow Fishway for three reasons: (i) short-term habitat disturbance was likely minimal compared with that from the Mill Dam removal, especially considering that the fishway maintained both the lentic nature of the upstream wetland and the lotic nature of downstream habitat; (ii) prior to removal of the Mill Dam, this structure would have facilitated passage only for those fishes that move between Sedgeunkedunk Stream and the Fields Pond wetland complex; and (iii) our first post-removal sampling episode occurred 9 months subsequent to fishway construction, after winter ice scour and spring flooding likely displaced fishes 
locally. The uppermost Brewer Lake Dam, located between Fields Pond and Brewer Lake, remains intact and continues to block passage further upstream in the watershed.

Our study incorporated a modification of a before-aftercontrol-impact design (BACI; Stewart-Oaten et al., 1986; Kibler et al., 2011), which accounts for naturally occurring temporal and spatial variation so that we can attribute differences in fish metrics to restoration efforts irrespective of background variation. A BACI design requires that pre-impact conditions and variability are known, which we established by sampling for 1 year before the restoration project began (before the Meadow Fishway installation) and 2years before the lowermost dam (Mill Dam) removal took place. We also monitored a reference system, Johnson Brook, which is a tributary of the Penobscot River located in Orrington, Maine (Figure 1). Johnson Brook flows out of Swetts Pond at $44^{\circ} 42^{\prime} 18^{\prime \prime} \mathrm{N}$ and $68^{\circ} 47^{\prime} 10^{\prime \prime} \mathrm{W}$ and debouches into the Penobscot River (at river $\mathrm{km} \mathrm{24)}$ at $44^{\circ} 42^{\prime} 08^{\prime \prime} \mathrm{N}$ and $68^{\circ} 49^{\prime} 50^{\prime \prime} \mathrm{W}$. This system includes a natural barrier (Clark's Falls, at stream km 2.2) and a dam at the outlet of Swetts Pond (at stream km 5.5) that were presumed to be functionally analogous to the dams located in Sedgeunkedunk Stream.

\section{Study design}

Five 100-m sampling stations were selected along Sedgeunkedunk Stream (Figure 1). Site S1 is located at stream km 0.450.55 , immediately downstream of the former Mill Dam and was the only site accessible to anadromous fish prior to the removal of Mill Dam. Site S2 is located immediately upstream of the Mill Dam site at stream km 0.62-0.72. Site S3 is located approximately halfway between the Mill Dam and Meadow Dam sites at stream km 2.5-2.6. Site S4 is located immediately downstream of the Meadow Dam/Fishway site at stream $\mathrm{km}$ 5.1-5.2. Site S5 is located in the headwaters upstream of Brewer Lake at stream km 8.2-8.3. Site S5 is located upstream of another barrier (Brewer Lake Dam) not scheduled for removal, and because this reach should not be affected by barrier removals farther downstream, it serves as a reference site within Sedgeunkedunk Stream. Three 50-m sampling locations were selected along Johnson Brook for comparison with sites on Sedgeunkedunk Stream before and after barrier removal (Figure 1). These sites were limited to $50 \mathrm{~m}$ in length because of logistical access problems. Site $\mathrm{J} 1$ is located immediately downstream of Clark's Falls at stream km 3.62-3.67. Site J2 is located immediately upstream of Clark's Falls at stream km 3.71-3.76. Site J3 is located immediately downstream of the dam at the outlet of Swetts Pond at stream km 7.35-7.40. Monitoring multiple sites on both streams allowed us to quantify longitudinal variability in both the treatment and reference stream before the impact of dam removal occurred. This will improve our ability to detect changes after dam removal, especially if the strength of effect varies in proximity to the perturbation of the dam or its removal (Hayes et al., 2003; Underwood 1994). All sites were characterized by riffle and glide mesohabitats and coarse substrate. Although site S2 was located within $25 \mathrm{~m}$ of the Mill Dam and reflected the legacy of a historic impoundment (straightened channel and herbaceous riparian vegetation), Mill Dam had been decommissioned for several years prior to our study and the impoundment was not maintained actively, and thus this site was still lotic in nature.

\section{Fish surveys}

Each location on Sedgeunkedunk Stream was sampled in August of 2007. In 2008 and 2009, each location on both streams was sampled twice per year, once in the spring (late May) as soon as spring runoff subsided and again in late summer (late July to mid August) during low-flow conditions. Within each season, no more than 10 days elapsed between the first and last sites sampled. Fishes were sampled using backpack electrofishers; electrofisher settings were $30-60 \mathrm{~Hz}, 20 \%$ duty cycle and $\sim 300-500 \mathrm{~V}$, depending on measured ambient conductivity. Settings were optimized for maximum power transfer (Reynolds 1996) and were not changed within any sampling event. Each site was closed to immigration and emigration during the survey with 3-mm-mesh blocking nets. All fishes caught were identified to species, and the first 300 individuals of each species at each site were measured [total length (TL), $\mathrm{mm}$, and mass, $0.1 \mathrm{~g}]$. Except for incidental mortality ( $<2 \%$ for all sampling events), fishes were returned to the stream alive, and delayed mortality was presumed to be negligible. Biannual electrofishing was assumed to not influence the fish community measurably (Latimore and Hayes 2008). In summer 2008, all sampling was completed before the construction of the Meadow Fishway. In 2009, the summer round of sampling occurred within 7 days after the removal of the Mill Dam. We sampled sites S1 and S2 3 days after the dam removal, as soon as that stream had cleared of suspended sediment enough for us to electrofish effectively.

\section{Abundance estimates}

Fish abundance at each site was estimated by conducting three-pass depletion estimates (Zippin, 1958) except for spring 2007 when we conducted two-pass depletions. At each sampling reach, stream width was measured at 10 locations and the area estimated as the product of reach length and mean width. Typically, mean widths were $<5 \mathrm{~m}$. This sampling area was used in our estimates of total fish density (number of fish $/ \mathrm{m}^{2}$ ) with associated variances for each sampling location and combined with mean mass to yield 
estimates of biomass density (grammes of fish $/ \mathrm{m}^{2}$; Hayes et al., 2007). Differences in density and biomass among reaches and over time were assessed by inspecting overlap of $95 \%$ confidence intervals, which gives a conservative estimate of the significance and magnitude of such differences (Payton et al., 2003). Although American eel (Anguilla rostrata) were present and abundant at all sites at all times, our catchability was extremely low for small elvers $(<100 \mathrm{~mm} \mathrm{TL})$ so we limited the analysis of these data to qualitative, rather than quantitative, measures (i.e. presence/absence). Similarly, alewife, rainbow smelt and sea lamprey were not included in measures of density because they were present briefly during the spring spawning run and only downstream of Mill Dam.

\section{Assemblage assessment}

Temporal and longitudinal changes in the fish assemblages were characterized by three methods. First, species richness was determined by noting presence/ absence of each species. Comparisons of species richness among sites were made using a Friedman test and Tukey multiple comparisons (Zar, 1999). Presence/absence was also used to describe species distribution before barrier removal. Second, we calculated a Shannon Wiener species diversity index (Krebs, 1989)

$$
H^{\prime}=-\sum P_{i} \ln P_{i}
$$

for each site over time, where $P_{i}$ is the proportion of the population belonging to species $i$. Third, we calculated a Sorensen's similarity index (Krebs, 1989)

$$
Q S=2 c /(a+b)
$$

where $c$ is the number of species in common between two sites and $a$ and $b$ are the total number of species in each of the two sites. In this index of similarity, values range from 0 (complete dissimilarity) to 1 (identity). Finally, to examine how fish community structure varied in space and changed over time, we used non-metric multidimensional scaling (NMDS; PC-ORD 4.0 MjM Software, Gleneden Beach, Oregon, USA; McCune and Grace 2002) based on a Sorensen distance matrix derived from raw abundance data. We plotted the NMDS scores to better visualize similarities and differences among sites and trajectories within each site over time (e.g. Taylor 2010), including any changes coincident with the Mill Dam removal.

\section{RESULTS}

\section{Richness and diversity}

Over the courrse of this study, we encountered 22 species and 26873 individual fish (Table 1). In 2007, we captured 4760 fishes in Sedgeunkedunk Stream. In 2008, we captured 7872 fishes in Sedgeunkedunk Stream and 3693 fishes in Johnson Brook. In 2009, we captured 8516 fishes in Sedgeunkedunk Steam and 2032 in Johnson Brook. Four species were ubiquitous over time and space in both streams: American eel, eastern blacknose dace (Rhinichthys a. atratulus), fallfish (Semotilus corporalis) and white sucker (Catostomus commersoni). In Sedgeunkedunk Stream prior to dam removal, species richness was always greatest $(p<0.03)$ at site $\mathrm{S} 1$, immediately downstream of Mill Dam (Figure 2); 14 species were encountered in the 2008 and 2009 sampling episodes at S1 (nine species were encountered

Table I. Occurrence of species, before the removal of the Mill Dam, in study sites in Sedgeunkedunk Stream and Johnson Brook,

\begin{tabular}{|c|c|c|c|c|c|c|}
\hline Species & $\mathrm{S} 1$ & $\mathrm{~S} 2$ & S3 & S4 & S5 & $\mathrm{J} 1 \mathrm{~J} 2 \mathrm{~J} 3$ \\
\hline Atlantic salmon & $\bigcirc$ & & & & & \\
\hline Blacknose dace & - & ○ & ○ & ○ & O & 0 \\
\hline Bluntnose minnow & $\bigcirc$ & & & & & \\
\hline Brown bullhead & 1 & $\bigcirc$ & & 1 & 0 & ( \\
\hline Creek chub & $\bigcirc$ & & & $\bigcirc$ & & ○ \\
\hline Pumpkinseed sunfish & $\bigcirc$ & $\bigcirc$ & O & $\bigcirc$ & O & 1 \\
\hline Common shiner & 1 & $\bigcirc$ & $\bigcirc$ & 1 & 1 & 0 \\
\hline Eastern brook trout & & $\bigcirc$ & O & & & 1 \\
\hline Chain pickerel & & & & $\bigcirc$ & & 1 \\
\hline American eel & ? & 1 & 1 & 1 & 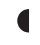 & 100 \\
\hline Fathead minnow & $\bigcirc$ & & & $\bigcirc$ & & - 0 \\
\hline Fallfish & O & 0 & - & 1 & ○ & 101 \\
\hline Finescale dace & $\bigcirc$ & & & & & \\
\hline Golden shiner & ○ & & & 1 & 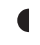 & 1 \\
\hline Northern redbelly dace & ○ & & & 1 & & $\bigcirc$ \\
\hline Ninespine stickleback & $\bigcirc$ & & & & & $\bigcirc$ \\
\hline Redbreast sunfish & 0 & 1 & 1 & $\bigcirc$ & $\mathrm{O}$ & 1 \\
\hline White sucker & 0 & 0 & ○ & - & 1 & 000 \\
\hline Smallmouth bass & 1 & & & & & 0 \\
\hline White perch & & & & & & 1 \\
\hline Black crappie & & & & $\bigcirc$ & & \\
\hline Yellow perch & $\bigcirc$ & & & & & \\
\hline Alewife & $*$ & & & & & \\
\hline Rainbow smelt & $*$ & & & & & \\
\hline Sea Lamprey & $*$ & & & & & \\
\hline $\begin{array}{l}\text { density }=0.1 \mathrm{fish} \\
\text { density }=0.01 \mathrm{fish} \\
\text { density }<0.01 \mathrm{fish} \\
* \text { no density estimat }\end{array}$ & & & & & & \\
\hline
\end{tabular}
Penobscot Co., Maine, 2007-2009 


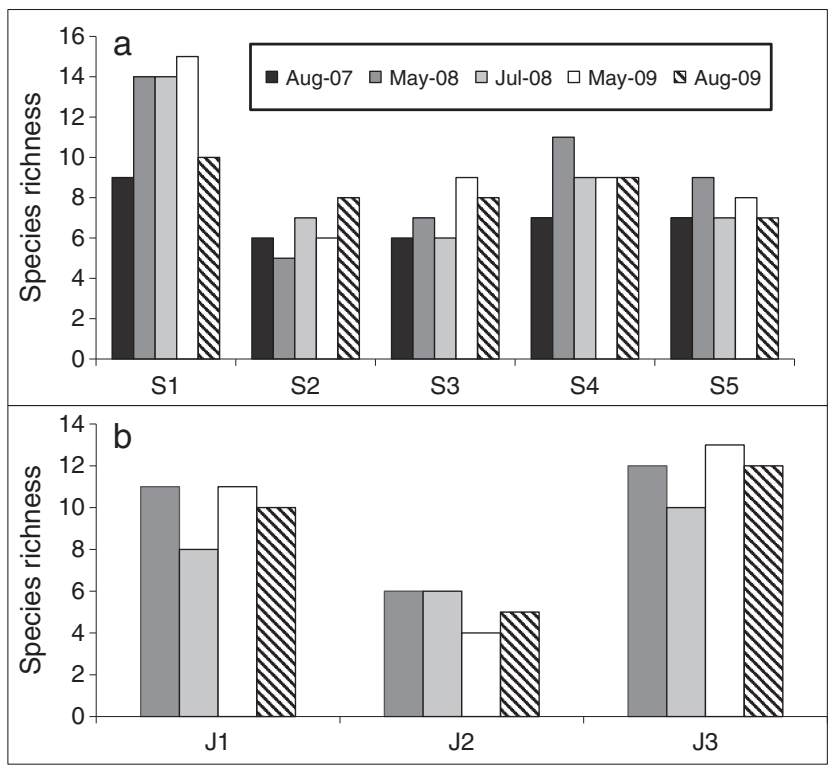

Figure 2. Species richness at sampling sits along stream gradient in Sedgeunkedunk Stream (a) and Johnson Brook (b) during spring and summer sampling episodes from 2007 to 2009

in 2007). This richness decreased to either five or six species at site $\mathrm{S} 2$. Species richness remained at this minimal level at site $\mathrm{S} 3$ at all sampling episodes, but had risen to 9 or 11 species at site S4. Site S5 had eight species present in each spring sampling and seven species present in each summer sampling. Prior to dam removal, juvenile Atlantic salmon were encountered only at site S1. In the fall of 2008 one Atlantic salmon parr was captured $(\mathrm{TL}=152 \mathrm{~mm})$, and in the spring of 2009 , one Atlantic salmon fry $(\mathrm{TL}=30 \mathrm{~mm})$ was captured. Immediately after removal of the Mill Dam, species richness at site S1 decreased from 14 to 10, and the richness at the sites upstream were similar to that found in previous samplings. Species no longer found at site $\mathrm{S} 1$ following the dam removal were: northern redbelly dace (Phoxinus eos), finescale dace (Phoxinus neogaeus), fathead minnow (Pimephales promelas) and ninespine stickleback (Pungitius pungitius). However, Atlantic salmon parr were captured at sites S2 $(n=5$, mean $\mathrm{TL}=83 \mathrm{~mm})$ and $\mathrm{S} 3(n=55$, mean $\mathrm{TL}=65 \mathrm{~mm})$.In Johnson Brook, species richness at site J1 (downstream of Clark's Falls) ranged from 8 to 11 and decreased to four to six species at site J2 (upstream of Clark's Falls). Richness was always highest at site J3 (downstream of Swetts Pond Dam; $p<0.05$ ), ranging from 10 to 13 species. No changes in species richness were detected in Johnson Brook coincident with the Mill Dam removal in Sedgeunkedunk Stream. Species diversity in Sedgeunkedunk Stream was always highest at sites S1 and S5 (1.04 to 1.67; Table 2) and usually lowest at S2 and S3 (0.41 to 1.03; Table 2). Prior to the Mill Dam removal, sites S1, S4 and S5 had high pairwise Sorensen's Similarity Index values (i.e., QS $>0.70$ ) but were
Table II. Shannon Wiener diversity index values for fish community composition in sites in Sedgeunkedunk Stream and Johnson Brook, Penobscot Co., Maine, 2007-2009

a. Sedgeunkedunk Stream

\begin{tabular}{lccccc}
\hline & S1 & S2 & S3 & S4 & S5 \\
\hline July 2007 & 1.18 & 1.03 & 0.51 & 0.82 & 1.58 \\
May 2008 & 1.63 & 0.66 & 0.67 & 1.16 & 1.67 \\
August 2008 & 1.22 & 0.77 & 0.60 & 0.65 & 1.04 \\
May 2009 & 1.40 & 0.82 & 0.69 & 0.56 & 1.06 \\
August 2009 & 1.44 & 0.82 & 0.69 & 0.56 & 1.06 \\
b. Johnson Brook & & & & & \\
May 2008 & J1 & J2 & J3 & & \\
August 2008 & 1.12 & 1.40 & 1.88 & & \\
May 2009 & 1.06 & 1.38 & 1.92 & & \\
August 2009 & 1.36 & 1.15 & 1.58 & & \\
\hline
\end{tabular}

less similar to sites S2 and S3, which themselves were highly similar (Table 3). In Johnson Brook, diversity was always highest at site $\mathrm{J} 3$ (1.58 to 2.22) and lowest at site $\mathrm{J} 1$ and J2 (1.06 to 1.41 ; Table 2 ). Immediately post-dam removal, diversity increased at site S2 (Table 2), and all of the sites in Sedgeunkedunk Stream became more similar (Table 3). Again, no coincident changes were observed in Johnson Brook after dam removal.

\section{Density and biomass}

Total fish density in Sedgeunkedunk Stream ranged from 0.1 to $3.2 \mathrm{fish} / \mathrm{m}^{2}$; values were highest at site $\mathrm{S} 1$ (and lowest at sites S2 and S5) during all sampling occasions before the

Table III. Sorensen's similarity index values comparing fish community composition between sites in Sedgeunkedunk Stream and Johnson Brook, Penobscot Co., Maine, 2009

a. Sedgeunkedunk Stream

\begin{tabular}{lccccc}
\hline & S1 & S2 & S3 & S4 & S5 \\
\hline S1 & - & 0.53 & 0.57 & 0.80 & 0.73 \\
S2 & 0.67 & - & 0.80 & 0.53 & 0.57 \\
S3 & 0.78 & 0.88 & - & 0.78 & 0.82 \\
S4 & 0.84 & 0.71 & 0.82 & - & 0.94 \\
S5 & 0.82 & 0.80 & 0.93 & 0.88 & - \\
b. Johnson Brook & & & & \\
\multicolumn{1}{l}{ J1 } & J1 & J2 & J3 & & \\
J2 & 0.67 & 0.53 & 0.67 & & \\
J3 & 0.82 & 0.59 & - & & \\
\hline
\end{tabular}

Values range from 0 (no similarity) and 1 (identity). Values above the diagonal are from before the dam removal. Values below the diagonal are from after the dam removal. 
removal of the Mill Dam (Figure 3a). Densities followed a pattern along the stream gradient of reaching a maximum at $\mathrm{S} 1$, declining sharply upstream at $\mathrm{S} 2$, increasing upstream towards sites S3 and S4 and then decreasing sharply towards site S5. Total fish density in Johnson Brook showed a consistent longitudinal pattern during all sampling events. Density ranged from 0.4 to $5.0 \mathrm{fish} / \mathrm{m}^{2}$ and was always higher at site J1 than at sites J2 and J3 (Figure 3b). Biomass in Sedgeunkedunk Stream prior to dam removal ranged from $1.1 \mathrm{~g} / \mathrm{m}^{2}$ to $11.5 \mathrm{~g} / \mathrm{m}^{2}$ and was more variable over space and time than was abundance (Figure 4a); only site S4 showed high consistency in values. Conversely, patterns in Johnson Brook were consistent; values ranged from 0.8 to $15.0 \mathrm{~g} / \mathrm{m}^{2}$ and were always lowest at $\mathrm{J} 2$ and highest at $\mathrm{J} 3$.

Abundance metrics in Sedgeunkedunk Stream changed markedly following the removal of the dam. Fish density at site $\mathrm{S} 1$ showed a significant decline to a minimum of $0.9 \mathrm{fish} / \mathrm{m}^{2}$, whereas the density at site $\mathrm{S} 2$ increased more than fivefold to $2.9 \mathrm{fish} / \mathrm{m}^{2}$ (Figure 3a). Density also increased at sites S3 and S4 but remained low at S5 (0.1 fish $/ \mathrm{m}^{2}$ ). There was no change in the spatial pattern in Johnson Brook over this period (Figure 3b). After dam removal, biomass in Sedgeunkedunk Stream followed the same pattern as did density: a $75 \%$ reduction from previous maximum value in site $\mathrm{S} 1\left(11.5\right.$ to $\left.3.71 \mathrm{~g} / \mathrm{m}^{2}\right)$, an $800 \%$ increase from previous minimum value in site S2 (1.1 to $9.6 \mathrm{~g} / \mathrm{m}^{2}$ ), a decline towards site $\mathrm{S} 3$, an increase towards site S4 and then a decline to a minimum value in S5 (Figure 4a). Patterns of biomass in Johnson Brook were identical to

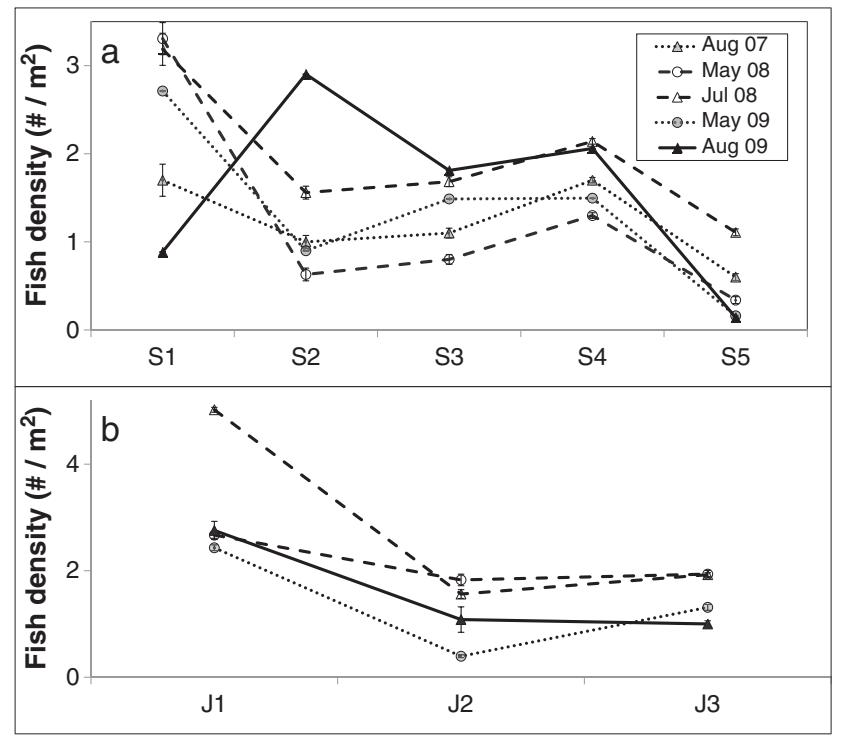

Figure 3. Fish density $\left(\# / \mathrm{m}^{2}\right)$ at sites along the stream gradient of Sedgeunkedunk Stream (a) and Johnson Brook (b) during spring and summer sampling episode from 2007 to 2009. Error bars represent $\pm 2 \mathrm{SE}$

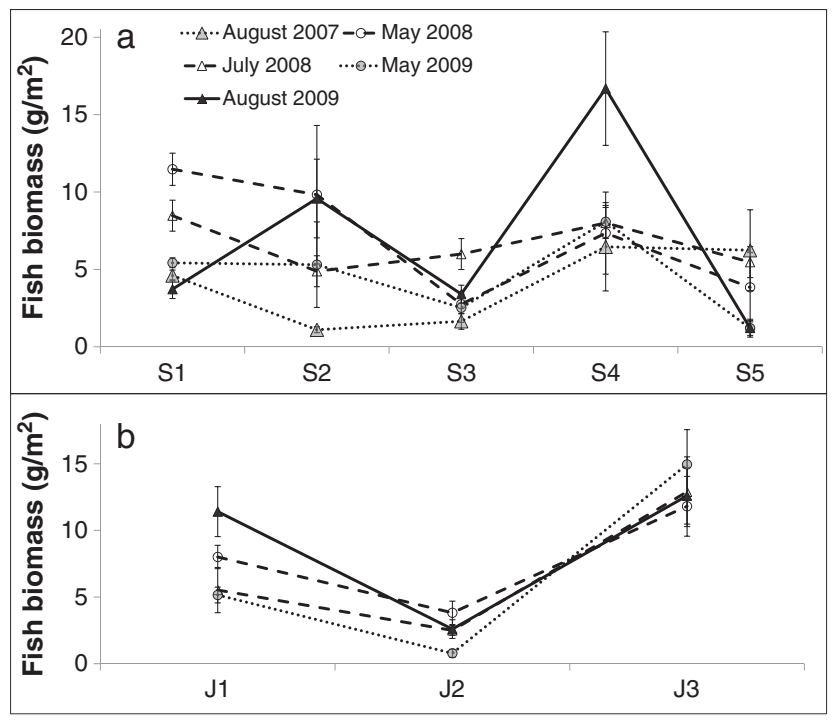

Figure 4. Fish biomass $\left(\mathrm{g} / \mathrm{m}^{2}\right)$ at sites along stream gradient of Sedgeunkedunk Stream (a) and Johnson Brook (b) during spring and summer sampling episode from 2007 to 2009. Error bars represent $\pm 2 \mathrm{SE}$

pre-dam conditions (Figure 4b). Blacknose dace was, often by an order of magnitude, the most abundant species at all sampling locations and times. Because patterns in density and biomass of blacknose dace were nearly identical to those for all fishes (Figures 3 and 4), these graphs are not presented. After the removal of the Mill Dam, the density of blacknose dace at site $\mathrm{S} 1$ decreased from a previous maximum of 2.0 to $0.4 \mathrm{fish} / \mathrm{m}^{2}$, whereas the density at site $\mathrm{S} 2$ more than tripled from a previous minimum of 0.4 to 2.6 fish $/ \mathrm{m}^{2}$. Blacknose dace density in Johnson Brook also showed a consistent pattern at all sampling events, with density and biomass both higher at site $\mathrm{J} 1$ than at sites $\mathrm{J} 2$ and $\mathrm{J} 3$.

\section{Assemblage structure}

The NMDS produced a stable two-dimensional solution that explained $87 \%$ of the variance in the abundance data set (axis 1, $R^{2}=0.55$; axis $2, R^{2}=0.32$; Figure 5). Blacknose dace $(r=0.87)$, white sucker $(r=0.59)$ and fathead minnow (Pimephales promelas) $(r=0.39)$ were correlated most positively with axis 1 , whereas white perch (Morone americana) $(r=-0.17)$, creek chub (Semotilus atromaculatus) $(r=-$ $0.16)$, and chain pickerel (Esox niger) $(r=-0.11)$ were correlated most negatively with axis 1 (Figure 6). Creek chub $(r=0.85)$, white perch $(r=0.47)$ and common shiner (Luxilus cornutus) $(r=0.39)$ were correlated most positively with axis 2, whereas blacknose dace $(r=-0.53)$, fallfish $(r=-$ $0.34)$ and Atlantic salmon $(r=-0.19)$ were correlated most negatively with axis 2 (Figure 6). Ordination scores of site S1 were consistent from May 2008 through 2009 but 


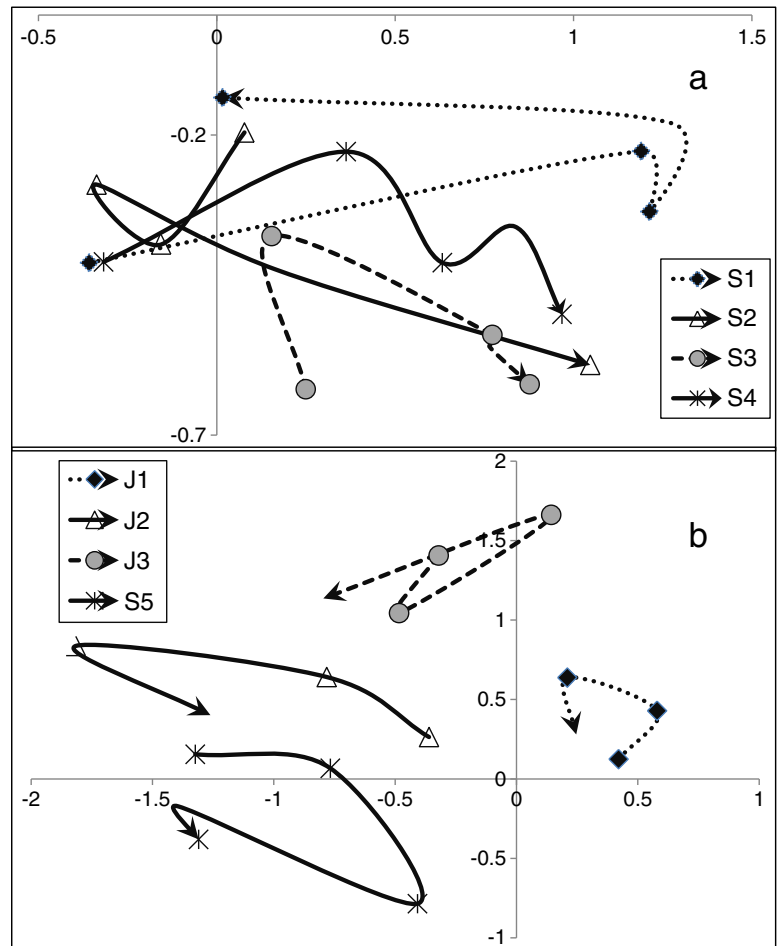

Figure 5. Ordinations of first two non-metric multidimensional scaling axes scores for fish abundance data in Sedgeunkedunk Stream and Johnson Brook within each site over time. Arrows indicate trends over time (starting from August 2007 or May 2008), and location of arrowhead indicates two-dimensional location of data from final sampling episode (August 2009). For clarity, sites S1-S4 are shown on top panel (a) and reference sites S5 and J1-J4 are shown in bottom

panel (b). Axis orientations differ between panels for clarity

trended strongly negative on axis 2 after dam removal. The ordination scores of sites S3 and S4 followed a similar trajectory as $\mathrm{S} 1$ prior to dam removal, but the trajectories diverged after dam removal. Site 2 followed a very different trajectory as all other sites pre-dam removal, trending negative on both axes 1 and 2 but behaved similarly to sites S3 and S4 post-dam removal (Figure 5a). The reference sites (S5, J1, J2 and J3) each were more distinct in gradient space and exhibited more temporal and spatial variability than did sites S1-S4 but showed no discernable trends over time coincident with the dam removal (Figure 5b).

\section{DISCUSSION}

Over the course of this study, longitudinal and temporal patterns in Sedgeunkedunk Stream (before the removal of the Mill Dam) and Johnson Brook (at all times) were consistent, and this consistency allowed us to detect the immediate effects of the disturbance that took place after the removal

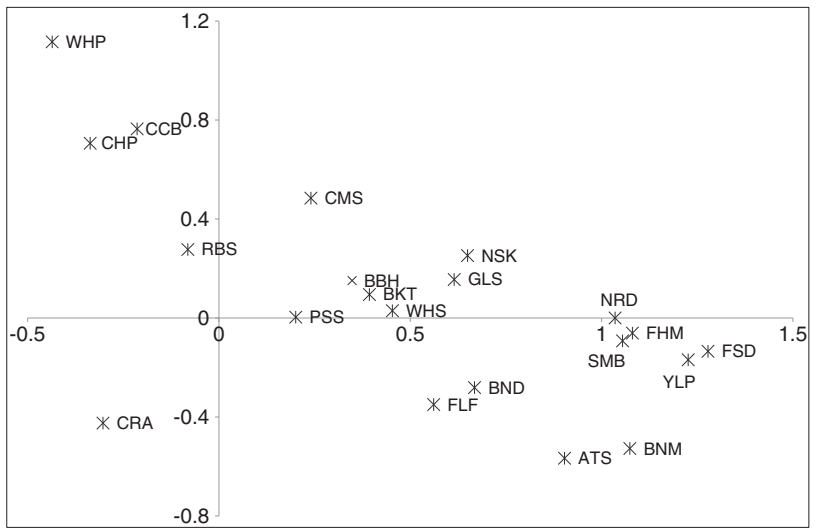

Figure 6. Fish species ordinations on first two non-metric multidimensional scaling axes. Species abbreviations: ATS (Atlantic salmon), BKT (eastern brook trout), BBH (brown bullhead), BND (blacknose dace), BNM (bluntnose minnow), CHP (chain pickerel), CMS (common shiner), CRA (black crappie), CRC (creek chub), FHM (fathead minnow), FLF (fallifish), FSD (finescale dace), GSH (golden shiner), NRD (northern redbelly dace), NSK (ninespine stickleback), PSS (pumpkinseed sunfish), RBS (redbreast sunfish), SMB (smallmouth bass), WHS (white sucker), WHP (white perch), YLP (yellow perch)

of the Mill Dam. Although fish densities varied by up to $200 \%$ within sites over time prior to dam removal, the longitudinal pattern in density was consistent in Sedgeunkedunk Stream across all sampling episodes prior to dam removal and consistent in Johnson Brook throughout the study. Similarly, fish biomass varied by up to $800 \%$ among sampling episodes within sites, but the overall longitudinal pattern showed similar consistency as density. The precision of our density estimates was very high, which allowed us to detect spatial difference during any particular sampling episode as well as temporal differences within any particular site. Precision of our biomass estimates was lower than the precision of our density estimates but still allowed us some discriminatory ability to detect differences across space and time. Assemblage structure (as described by NMDS scores, similarities, diversity and richness) showed differences in baseline values and trajectories over time according to proximity to the Mill Dam. Because of the similarity of pre-removal longitudinal patterns in Johnson Brook and Sedgeunkedunk Stream and the low variability associated with them, along the stream gradient, we can expect to detect biologically meaningful changes in response to dam removal.

The presence of the Mill Dam in Sedgeunkedunk Stream influenced the composition and abundance of the fish assemblage along the stream gradient, as did the dam removal. The site directly below the dam (S1) most likely represented the natural habitat condition of the stream more closely than did sites between the two dams. Although affected by the hydrological disturbances associated with a dam, this was 
the only site readily accessible to fishes migrating from the Penobscot River and the Atlantic Ocean. This connectivity to a larger riverine system downstream allows for increased species richness and diversity (Smith and Kraft 2005). Migratory species (e.g. Atlantic salmon and ninespine stickleback) and resident species from the mainstem Penobscot River (e.g. smallmouth bass) could enter this section of stream. This section also has increased local habitat diversity because of its transition into the mainstem Penobscot including thermal variability and a freshwater tidal zone. Finally, because anadromous sea lamprey spawn and die in site S1, marine-derived nutrients and energy could be subsidizing increased fish abundance and biomass there (Nislow and Kynard 2009). Perhaps not surprisingly, S1 always contained the greatest richness and abundance of fishes prior to dam removal.

The study site located upstream of Mill Dam (S2) was a relatively straight, slow moving stretch that reflected a history of impoundment. The riparian zone consisted of grasses that had colonized the sediment deposited upstream of the dam and replaced the historic forest cover along the stream. The combination of the exposure, channel straightening and aggradation resulted seemingly in habitat homogeneity. This section of stream had fewer fish and lower species richness and diversity than all other sites. This is consistent with declines in fish richness and abundance associated with low-head dams in Great Lakes tributaries (Dodd et al., 2003) because of homogeneity of habitat and lack of connectivity (Angermeier and Smogor 1995). The fish assemblage in this section also contained more large-bodied species like fallfish and white sucker, which use deeper pools formed as a legacy of impoundments (Petts 1980; Swink and Jacobs 1983). Populations of small-bodied minnows, like blacknose dace, were dominated by smaller fish. All species found in this site were found at other sites. Whereas these decreases in abundance and diversity are to be expected as one travels upstream (Danehy et al., 1998; Grossman et al., 2010; Lotrich 1973; Sheldon 1968), the differences between these two sites were drastic and occurred over a distance of less than $100 \mathrm{~m}$. The differences in abundance and diversity between S1 and S5 were of similar magnitude as between $\mathrm{S} 1$ and $\mathrm{S} 2$ but were associated with a much greater longitudinal distance of $8 \mathrm{~km}$.

Species richness, diversity and the density of fish appeared to recover upstream from the formerly impounded site and likely represent an attenuating impact of the disturbance from the dam (Kinsolving and Bain 1993; Phillips and Johnston 2004). This strengthens the assertion that the assemblage at the site directly above the dam was a product of an interrupted longitudinal gradient. The fish assemblages at sites S3 and S4 became more similar to site S1 corresponding to a gradual recovery from the interruption caused by the Mill Dam. The relatively low (but remarkably consistent) fish density and biomass at site S5 (located much farther upstream in the watershed) probably resulted from two factors: reduced connectivity to downstream reaches (Lienesch et al., 2000) and a comparatively long distance from potential migrants or colonizers (Smith and Kraft 2005). More importantly, this headwaters reach is located in a steeper, more heavily forested section of the watershed and is characterized by lower temperatures and conductivity and shallower pools than in downstream sites. Thus, the potential abundance and diversity of fishes is probably minimized here (Danehy et al., 1998; Lotrich, 1973; Schlosser 1982), and the assemblage at this site is representative of a lightly impacted headwaters reach with little influence from anadromous fishes.

The pattern in Johnson Brook was similar to the longitudinal pattern that we found in Sedgeunkedunk Stream, although the differences above and below the impassable barrier were not as dramatic, and the distinct changes associated with the Mill Dam removal were not observed here. The site below the impassable falls (J1) showed higher species richness and diversity than the site directly above the falls (J2), which is probably a function of habitat disconnectivity similar to the effect of the Mill Dam in Sedgeunkedunk Stream. However, there were differences between sites $\mathrm{S} 2$ and $\mathrm{J} 2$ that likely reflect the difference in the nature of the two barriers. Although the waterfall is probably a barrier to upstream migration of most fishes (except American eel) under most conditions, it was not associated with a deforested, channelized and sedimented legacy of a constructed impoundment. It is therefore not surprising that the area upstream of a natural falls did not harbour a similarly depauperate assemblage dominated by larger-bodied species. There was, however, a decline in fish density, biomass and species richness above the waterfall in Johnson Brook analogous to what was observed above the Mill Dam in Sedgeunkedunk Stream. Species that were found at S1 and J1, and not at S2 or J2, included fathead minnow, golden shiner (Notemigonus crysoleucas), northern redbelly dace (Phoxinus eos), and ninespine stickleback. The most upstream site in Johnson Brook (J3) contained densities similar to or lower than the site below the falls but contained greater biomass and species richness. This is most likely due to its location below an old low-head dam located at the outlet of Swetts Pond. This site often held large-bodied species normally associated with a lentic environment that may have been washed downstream during floods in the spring and had persisted in a few pools associated with a road crossing culvert (such as brown bullhead Ameiurus nebulosus, chain pickerel and white perch). Predation by these species might explain the very low density of small-bodied fishes like blacknose dace.

Locations of sites and fish species in ordination space provide hypotheses about underlying patterns seen in richness 
and diversity. Although the meanings of axes 1 and 2 are not definitively interpretable, the upper-left quadrant of the ordination is dominated by lentic or pool-dwelling native species (such as white perch, creek chub, chain pickerel and redbreast sunfish) associated with sites further upstream in both Sedgeunkedunk and Johnson watersheds. The lowerright quadrant was dominated by an interesting assemblage of lotic non-native species such as fathead minnow, bluntnose minnow and smallmouth bass but also native species like Atlantic salmon, finescale dace and northern redbelly dace, all of which are associated with the mainstem Penobscot River. The centre of ordination space is occupied by generalist native species typical of Maine streams: white sucker, brown bullhead, golden shiner, fallfish and blacknose dace. This gradient from upper-left to lower-right might represent a transition from a depauperate assemblage of pool-dwelling or 'landlocked' lentic species to a richer assemblage of both native and introduced stream-associated and riverine-associated species.

Three days after the removal of the Mill Dam on 14 August 2009 , we began post-removal sampling at site S1. The immediate response to associated siltation and turbidity was a decline in richness and abundance below the former dam location. Fish mortality can be expected during these types of events of increased flow and turbidity (Doeg and Koehn 1994). The data suggest that in this case, however, some of the observed decline in density was caused by movement rather than mortality. Although species richness did not increase immediately above the dam site, fish density increased by fivefold and biomass by eightfold. Successful colonization of former dam impoundments by downstream fish species has been shown (Catalano et al., 2007), but this movement occurred very quickly in our study (within days). Fish densities at sites S3 and S4 reached their highest levels in the study after the dam removal. Small stream fishes like blacknose dace can travel more than $1 \mathrm{~km}$ in a day (Albanese et al., 2003), making the rapid colonization of sites $\mathrm{S} 3$ and S4 by fish that previously occupied reaches below the dam plausible. Even if individuals did not migrate all the way up to site $\mathrm{S} 4$, it is possible that there could have been a cascading effect of displacement pushing fish upstream as densities increased in sites upstream of the former dam. In sites that were not affected by the removal of the Mill Dam (site S5 in Sedgeunkedunk Stream and all of the sites in Johnson Brook), we did not detect any deviations from the dominant patterns in abundance or community structure.

Another effect of the dam removal was the colonization of previously unavailable stream sections by juvenile Atlantic salmon. Prior to dam removal, we encountered juvenile Atlantic salmon below the dam (no more than one fish in each sample) but nowhere else in the system. Although landlocked Atlantic salmon are stocked in Brewer Lake to satisfy angling demand, no evidence of spawning has ever been observed in Sedgeunkedunk Stream (Greg Burr, Maine Department of Inland Fisheries and Wildlife, Jonesboro, ME, personal communication). In the sampling that took place within days following the dam removal, we captured five age 0+ Atlantic salmon parr at site S2 and 55 parr at site S3. The parr we observed were possibly juveniles moving up from the Penobscot River, or more likely offspring of anadromous adults that spawned in Sedgeunkedunk Stream below Mill Dam (Joan Trial, Maine Department of Marine Resources, Bangor, ME, personal communication). It remains to be seen whether returning adults will spawn in the newly accessible stream reaches, but Kiffney et al. (2009) found very rapid upstream colonization of Coho salmon (Oncorhynchus kisutch) in Cedar Creek, Washington (USA), after a fish ladder bypassed a century-old dam.

Dams have been in place in many New England watersheds for centuries. Throughout the region, dam removal is offered as the means to achieve the goal of river restoration (Graf 2003). Such efforts often are enacted without clear standards for ecologically successful restoration in place (Palmer et al., 2005) and without rigorous plans to monitor the response (Bernhardt et al., 2005). Despite the fact that dam removals can be expensive undertakings (and many times because of it), scarce funds are spent on assessment with little hope of generating quantitative results (Heinz Center 2002). Hart et al. (2002) lamented the fact that fewer than $5 \%$ of all dam removals in the USA have been coupled with rigorous biomonitoring efforts. Our results demonstrate clearly that the ecological effects of dam removal are quantifiable and repeatable and that dam removals may be a valuable tool in restoring ecological structure in aquatic ecosystems, particularly for the suite of diadromous and resident fish species in Maine. Our hope is that these findings will advance recovery efforts for diadromous fish populations in the northeast USA in three main areas.

First, in the context of adaptive management (Holling 1978), we note that large resource investments are currently being made with little empirical evidence to support the putative ecological benefits of different strategies for diadromous fish restoration. In Maine, decimated diadromous fish populations are the focus of substantial recovery efforts, including the endangered Atlantic salmon (NMFS and USFWS 2005). The scale of financial investment required to effect significant change in diadromous populations requires a careful analysis of costs and benefits of each potential strategy. Unfortunately, empirical evidence in the peer-reviewed literature is currently lacking to demonstrate quantitatively the true ecological effects of dam removal as they relate to diadromous fish recovery (Stanley and Doyle 2003). The lack of empirical data evaluating ecological shifts attributable to dam removal is quite surprising for several 
reasons. Most notably, there is clear guidance from several federal agencies involved in funding dam removals to use adaptive management concepts, such as the US Department of Interior guidance to incorporate adaptive management into resource management decisions (Williams et al., 2009). Without peer-reviewed publications demonstrating the ecological effects of dam removals as they relate to diadromous fish recovery, weighing the costs and benefits to evaluate risk in an adaptive management context is impossible. Effective conservation requires that practitioners know the costs and benefits of available conservation strategies and tools (Salafsky et al. 2002). The results reported in the previous sections of this article represent an important first step toward filling this large knowledge gap.

Second, there is a growing awareness of the need to consider community ecological theory in the context of restoration ecology (Palmer et al. 1997). In particular, Soulé et al. (2005) noted the importance of interspecific interactions (particularly in the context of endangered species management) and further suggested that these interactions should be considered and managed for explicitly in the case of endangered species. In the case of the endangered Atlantic salmon, accumulating evidence suggests that co-recovery of co-evolved suite of diadromous species may be a requisite to successful recovery efforts of Atlantic salmon (Saunders et al. 2006). Preliminary results from dam removals in Sedgeunkedunk Stream are suggestive of positive population effects on a number of diadromous species including one endangered species (Atlantic salmon), one species of concern (alewives) and one often-neglected species (sea lamprey, which is the focus of a separate manuscript). If subsequent population evaluations on Sedgeunkedunk Stream show positive population trends in these species, then dam removal may prove to be a parsimonious and cost-effective recovery tool for Atlantic salmon and other imperilled fishes.

Finally, we note that the practice of aquatic restoration has been enhanced greatly by focusing on restoration outcomes and measurable criteria for success (sensu Palmer et al. 2005). In the previous sections of this article, we have reported findings on the ecological condition of Sedgeunkedunk Stream, provided baseline information for subsequent evaluations regarding whether or not any lasting changes were effected as a result of dam removal in Sedgeunkedunk Stream and made publicly available pre-removal and post-removal assessment to date. This represents substantial progress toward completion of three of the five standards for ecologically successful river restoration proposed by Palmer et al. (2005). We hope that with sustained effort and evaluations into the future, Sedgeunkedunk Stream will serve as a model for evaluating ecological changes to small streams in the northeast USA as a result of dam removals and, over the long term, that these findings will be useful to decision makers in a truly adaptive management framework.

\section{SUMMARY/CONCLUSIONS}

In order to evaluate the response of fishes in small coastal streams to dam removal, it is important to quantify the baseline conditions and variability before the dam removal. In Sedgeunkedunk Stream, the presence of a dam disrupted the natural longitudinal gradients in fish density, biomass, diversity and richness such that these metrics were maximized in the reach downstream of the dam, minimized in the reach upstream of the dam and recovered upstream. Prior to dam removal, we found consistent patterns in space and over time, which should allow us to detect the changes that take place following the restoration project. Although metrics such as stream fish density and biomass can be highly variable over small spatial and temporal scales, our density estimates were very precise and were remarkably consistent over space even as the values varied over time. Biomass estimates were less precise, but the same general patterns remained. The only major deviation from this pattern occurred at the two sites immediately adjacent to the dam immediately after removal, and the magnitude of the difference coupled with the precision of our estimates allowed us to detect these changes. The disturbance associated with this dam removal resulted in faunal homogenization among reaches and higher diversity and abundance upstream of the former dam site, which was probably due in part to rapid upstream migration of fish from downstream reaches. These migrants included juveniles of anadromous Atlantic salmon. Continued monitoring will allow us to show how the stream fishes below the former dam site recover from the disturbance of dam removal and how the entire stream fish assemblage responds to a more natural hydrology and increased connectivity to large river and marine ecosystems. This study should offer insight into the recovery of small streams as centuries-long stress from habitat fragmentation and longitudinal interruption in energy and material flows is removed.

\section{ACKNOWLEDGEMENTS}

Funding for this project was provided by NOAA's National Marine Fisheries Service, the Maine USGS Cooperative Fish and Wildlife Research Unit, the University of Maine and the Maine Agriculture and Forestry Experiment Station. We also thank R. Cope, G. Goulette, D. Kircheis, T. Liebich, K. Mueller, J. Murphy, B. Perry, K. Ravana, D. Skall and T. Trinko (NOAA-NMFS) 
for assistance with sampling. We thank our field technicians Silas Ratten, Jacob Kwapiszeski, Ryan Haley, Scott Ouellette, Anthony Feldpausch, Michael Picard, Meghan Nelson, Derek Lucas and graduate students Paul Damkot and Gus Wathen (University of Maine) for their hard work. The Town of Orrington and the City of Brewer were especially gracious in accommodating our research. We also thank Dan Hayes (Michigan State University) for stimulating conversations and his valuable advice on study design. Dr. James Gore, Dr. Kevin Simon, Tim Sheehan, and three anonymous reviewers improved the quality of this manuscript greatly; all remaining errors are our own. This paper is Maine Agricultural and Forestry Station Publication Number 3160. Mention of trade names does not imply endorsement by the United States government.

\section{REFERENCES}

Albanese B, Angermeier PL, Gowan C. 2003. Designing mark-recapture studies to reduce the effects of distance weighting on movement distance distributions of stream fishes. Transactions of the American Fisheries Society 132: 925-939.

Angermeier PL, Smogor RA. 1995. Estimating number of species and relative abundances in stream-fish communities: effects of sampling effort and discontinuous spatial distributions. Canadian Journal of Fisheries and Aquatic Sciences 52: 936-949.

Baldigo BP, Warren DR. 2008. Detecting the response of fish assemblages to stream restoration: effects of different sampling designs. North American Journal of Fisheries Management 28: 919-934.

Benke AC. 1990. A perspective on America's vanishing streams. Journal of the North American Benthological Society 9: 77-88.

Benke AC, Hall CAS, Hawkins CP, Lowe-McConnell RH, Stanford JA, Suberkropp K, Ward JV. 1988. Bioenergetic considerations in the analysis of stream ecosystems. Journal of the North American Benthological Society 7: 480-502.

Bernhardt ES, Palmer MA, Allan JD, Alexander G, Barnas K, Brooks S, Carr J, Clayton S, Dahm C, Follstad-Shah J, Galat D, Gloss S, Goodwin P, Hart D, Hassett B, Jenkinson R, Katz S, Kondolf GM, Lake PS, Lave R, Meyer JL, O’Donnell TK, Pagano L, Powell B, Suddeth E. 2005. Sythesizing U.S. river restoration efforts. Ecology 308: 636-637.

Bilby RE, Fransen BR, Bisson PA. 1996. Incorporation of nitrogen and carbon from spawning Coho salmon into the trophic system of small streams: evidence from stable isotopes. Canadian Journal of Fisheries and Aquatic Sciences 53: 164-173.

Brock CS, Leavitt PR, Schindler DE, Quay PD. 2007. Variable effects of marine derived nutrients on algal production in salmon nursery lakes of Alaska during the past 300 years. Limnology and Oceanography 52: 1588-1598

Burroughs BA, Hayes DB, Klomp KD, Hansen JF, Mistak J. 2009. Effects of Stronach Dam removal on fluvial geomorphology in the Pine River, Michigan, United States. Geomorphology 110: 96-107.

Burroughs BA, Hayes DB, Klomp KD, Hansen JF, Mistak J. 2010. The effects of the Stronach Dam removal on fish in the Pine River, Manistee County, Michigan. Transactions of the American Fisheries Society 139: 1595-1613.

Bushaw-Newton KL, Hart DD, Pizzuto JE, Thomson JR, Egan J, Ashley JT, Johnson TE, Horwitz RJ, Keeley M, Lawrence J, Charles DF, Gatenby C, Kreeger DA, Nightengale T, Thomas RL, Velinsky DJ. 2002. An integrative approach towards understanding ecological responses to dam removal: the Manatawny Creek study. Journal of American Water Resources Association 38: 1581-1599.

Catalano MJ, Bozek MA, Pellett TD. 2007. Effects of dam removal on fish assemblage structure and spatial distributions in the Baraboo River, Wisconsin. North American Journal of Fisheries Management 27: 519-530.

Danehy RJ, Ringler NH, Stehman SV, Hassett JM. 1998. Variability of fish densities in small catchments. Ecology of Freshwater Fish 7: 36-48.

Dodd HR, Hayes DB, Baylis JR, Carl LM, Goldstein JD, McLaughlin RL, Noakes DLG, Porto LM, Jones ML. 2003. Low-head sea lamprey barrier effects on stream habitat and fish communities in the Great Lakes. Journal of Great Lakes Research 29 (Supplement 1): 386-402.

Doeg TJ, Koehn DA. 1994. Effects of draining and desilting a small weir on downstream fish and macroinvertebrates. Regulated Rivers 9: 263-277.

Doyle MW, Stanley EH, Orr CH, Selle AR, Sethi SA, Harbor JM. 2005. Stream ecosystem response to small dam removal: lessons from the Heartland. Geomorphology 71: 227-244.

Dufour S, Piégay H. 2009. From the myth of a lost paradise to targeted river restoration: forget natural references and focus on human benefits. River Research and Applications 25: 568-581.

Ehrlich PR, Holden JP. 1971. Impact of population growth. Science 171: 1212-1217

Flecker AS, McIntyre PB, Moore JW, Anderson JT, Taylor BW, Hall Jr. RO. 2010. Migratory fishes as material and process subsidies in riverine ecosystems. In Community Ecology of Stream Fishes: Concepts, Approaches, and Techniques, Gido KB, Jackson DA (eds). American Fisheries Society Symposium 73: Bethesda, MD; 559-592.

Garman GC. 1992. Fate and potential significance of postspawning anadromous fish carcasses in an Atlantic coastal river. North American Journal of Fisheries Management 121: 390-394.

Graf WL. 2003. Summary and perspectives. In Dam Removal Research: Status and Prospects, Graf WL (ed). The H. John Heinz III Center for Science, Economics and the Environment: Washington, DC; 1-22.

Grossman GD, Ratajczak RE, Farr MD, Wagner CM, Petty JT. 2010. Why there are fewer fish upstream. In Community Ecology of Stream Fishes: Concepts, Approaches, and Techniques, Gido KB, Jackson DA (eds). American Fisheries Society Symposium 73: Bethesda, MD; 63-82.

Hall CAS. 1972. Migration and metabolism in a temperate stream ecosystem. Ecology 53: 585-604.

Hart DD, Johnson TE, Bushaw-Newton KL, Horwitz RJ, Bednarek AT, Charles DF, Kreeger DA, Velinsky DJ. 2002. Dam removal: challenges and opportunities for ecological research and river restoration. Bioscience 52: 669-681.

Hayes DB, Baylis JR, Carl LM, Dodd HR, Goldstein JD, McLaughlin RL, Noakes DLG, Porto LM. 2003. Biological effects of low-head sea lamprey barriers: designs for extensive surveys and the value of incorporating intensive process-oriented research. Journal of Great Lakes Research 29(Supplement 1): 373-385.

Hayes DB, Bence JR, Kwak TJ, Thompson BE. 2007. Abundance, biomass, and production. In Analysis and Interpretation of Freshwater Fisheries Data, Guy CS, Brown ML (eds). American Fisheries Society: Bethesda, MD; 327-374.

Hayes DB, Dodd HR, Lessard JL. 2008. Conservation considerations for small dams on coldwater streams. In Reconciling Fisheries with Conservation: Proceedings of the Fourth World Fisheries Congress, Nielsen JL, Dodson JJ, Friedland K, Hamon TR, Musick J, Verspoor E (eds). American Fisheries Society Symposium 49: Bethesda, MD; 1791-1786.

Heinz Center. 2002. Dam removal: science and decision making. Available at http://www.heinzctr.org/publications/PDF/Dam_removal_full_report. pdf [accessed on 10/12/2010].

Holling CS (ed). 1978. Adaptive Environmental Assessment and Management. John Wiley \& Sons: London. 
Jackson DA, Peres-Neto PR, Olden JD. 2001. What controls who is where in freshwater fish communities - the roles of biotic, abiotic, and spatial factors. Canadian Journal of Fisheries and Aquatic Sciences 58: 157-170.

Jones NE. 2010. Incorporating lakes within the river discontinuum: longitudinal changes in ecological characteristics in stream-lake networks. Canadian Journal of Fisheries and Aquatic Sciences 67: 1350-1362.

Kibler KM, Tullos DD, Kondolf GM. 2011. Learning from dam removal monitoring: challenges to selecting experimental design and establishing significance of outcomes. River Research and Applications. doi: 10.1002/rra. 1415

Kiffney PM, Pess GR, Anderson JH, Faulds P, Burton K, Riley SC. 2009. Changes in fish communities following recolonization of the Cedar River, WA, USA by Pacific salmon after 103 years of local extirpation. River Research and Applications 25: 438-452.

Kinsolving AD, Bain MB. 1993. Fish assemblage recovery along a riverine disturbance gradient. Ecological Applications 3: 531-544.

Koster D, Lichter J, Lea PD, Nurse A. 2007. Historical eutrophication in a river-estuary complex in mid-coast Maine. Ecological Applications 17: $765-778$.

Krebs C. 1989. Ecological Methodology. HarperCollins: New York.

Latimore JA, Hayes DB. 2008. The vigor-organization-resilience concept of ecological health: lessons from temperate warmwater stream fish communities. In Proceedings of the Fourth World Fisheries Congress: Reconciling Fisheries with Conservation. American Fisheries Society Symposium 49, Nielsen J, Dodson J, Friedland K, Hamon T, Hughes N, Musick J, Verspoor E (eds). American Fisheries Society: Bethesda, MD; 1807-1813.

Lienesch PW, Lutterschmidt WI, Schaefer JF. 2000. Seasonal and longterm changes in the fish assemblage of a small stream isolated by a reservoir. The Southwestern Naturalist 45: 274-288.

Ligon FK, Dietrich WE, Trush WJ. 1995. Downstream ecological effects of dams. BioScience 45: 183-192.

Limburg KE, Waldman JR. 2009. Dramatic declines in North Atlantic diadromous fishes. BioScience 59: 955-965.

Lotrich VA. 1973. Growth, production, and community composition of fishes inhabiting a first-, second-, and third-order stream of eastern Kentucky. Ecological Monographs 43: 377-397.

McCune B, Grace JB. 2002. Analysis of Ecological Communities. MJM Software Design: Glenden Beach, Oregon.

Mitchell SC, Cunjak RA. 2007. Stream flow, salmon and beaver dams: roles in the structuring of stream fish communities within an anadromous salmon dominated stream. Journal of Animal Ecology 76: 1062-1074.

Montgomery DR. 2003. King of Fish: The Thousand-Year Run of Salmon. Westview Press: Boulder, CO.

Morita K, Yamamoto S. 2002. Effects of habitat fragmentation by damming on the persistence of stream-dwelling charr populations. Conservation Biology 16: 1318-1325.

National Marine Fisheries Service (NMFS) and US Fish and Wildlife Service (USFWS). 2005. Final Recovery Plan for the Gulf of Maine Distinct Population Segment of Atlantic Salmon (Salmo salar). National Marine Fisheries Service: Silver Spring, MD, USA.

Nislow KH, Kynard BE. 2009. The role of anadromous sea lamprey in nutrient and material transport between marine and freshwater environments. American Fisheries Society Symposium 69: 485-494.

Palmer MA, Ambrose RF, Poff NL. 1997. Ecological theory and community restoration ecology. Restoration Ecology 5: 291-300.

Palmer MA, Bernhardt ES, Allen JD, Lake PS, Alexander G, S Brooks, Carr J, Clayton S, Dahm CN, Follstad Shah J, Galat DL, Gloss S, Goodwin P, Hart DD, Hassett B, Jenkinson R, Kondolf KM, Lave R, Meyer JL, O’Donnell TK, Pagano L, Sudduth E. 2005. Standards for ecologically successful river restoration. Journal of Applied Ecology 42: 208-217.
Payton ME, Greenstone MH, Schenker N. 2003. Overlapping confidence intervals or standard error intervals: what do they mean in terms of statistical significance? Journal of Insect Science 3: 34.

Petts GE. 1980. Long-term consequences of upstream impoundment. Environmental Conservation 7: 325-332.

Phillips BW, Johnston CE. 2004. Fish assemblage recovery and persistence. Ecology of Freshwater Fishes 13: 145-153.

Porto LM, McLaughlin RL, Noakes DLG. 1999. Low-head barrier dams restrict the movements of fishes in two Lake Ontario streams. North American Journal of Fisheries Management 19: 1028-1036.

Pringle CM. 1997. Exploring how disturbance is transmitted upstream: going against the flow. Journal of the North American Benthological Society 16: 425-438.

Quinn JW, Kwak TJ. 2003. Fish assemblage changes in an Ozark River after impoundment: a long-term perspective. Transactions of the American Fisheries Society 132: 110-119.

Resh VH, Brown AV, Covich AP, Gurtz ME, Li HW, Minshall GW, Reice SR, Sheldon AL, Wallace JB, Wissmar RC. 1988. The role of disturbance in stream ecology. Journal of the North American Benthological Society 7: 433-455.

Reynolds JB. 1996. Electrofishing. In Fisheries Techniques, Murphy BR, Willis DW (eds). American Fisheries Society: Bethesda, MD; 221-253.

Rounsefell GA, Stringer LD. 1945. Restoration and management of the New England alewife fisheries with special reference to Maine. Transactions of the American Fisheries Society 73: 394-424.

Salafsky N, Margolus R, Redford KH, Robinson JG. 2002. Improving the practice of conservation: a conceptual framework and research agenda for conservation science. Conservation Biology 16: 1469-1479.

Saunders R, Hachey MA, Fay CW. 2006. Maine's anadromous fish community: past, present, and implications for Atlantic salmon recovery. Fisheries 31: 537-547.

Schlosser IJ. 1982. Fish community structure and function along two habitat gradients in a headwater stream. Ecological Monographs 52: $395-414$.

Schmetterling DA, Adams SB. 2004. Summer movements within the fish community of a small montane stream. North American Journal of Fisheries Management 24: 1163-1172.

Sheldon AL. 1968. Diversity and longitudinal succession in stream fishes. Ecology 49: 194-198.

Smith T, Kraft CE. 2005. Stream fish assemblage in relation to landscape position and local habitat variables. Transactions of the American Fisheries Society 134: 430-440.

Soulé ME, Estes JA, Miller B, Honnold DL. 2005. Strongly interacting species: conservation policy, management, and ethics. Bioscience 55: 168-176.

Stanley EH, Doyle MW. 2003. Trading off: the ecological effects of dam removal. Frontiers in Ecology and the Environment 1: 15-22.

Stewart-Oaten A, Murdoch WW, Parker KR. 1986. Environmental impact assessment: "pseudoreplication" in time? Ecology 67: 929-940.

Stockner JG, Rydin E, Hyenstrand P. 2000. Cultural oligotrophication: causes and consequences for fisheries resources. Fisheries 25: 7-14.

Swink WD, Jacobs KE. 1983. Influence of a Kentucky flood-control reservoir on the tailwater and headwater fish populations. North American Journal of Fisheries Management 3: 197-203.

Taylor CM. 2010. Covariation among plains stream assemblages, flow regimes, and patterns of water use. In Community Ecology of Stream Fishes: Concepts, Approaches, and Techniques, Gido KB, Jackson DA (eds). American Fisheries Society Symposium 73: Bethesda, MD; $447-459$.

Underwood AJ. 1994. On beyond BACI: sampling designs that might reliable detect environmental disturbances. Ecological Applications 1: $3-15$. 
Vannote RL, Minshall GW, Cummins KW, Sedell JR, Cushing CE. 1980. The river continuum concept. Canadian Journal of Fisheries and Aquatic Sciences 37: 130-137.

Vitousek PM, Mooney HA, Lubchenco J, Melillo JM. 1997. Human domination of Earth's ecosystems. Science 277: 494-499.

Ward JV, Stanford JA. 1983. The serial discontinuity concept of lotic ecosystems. In Ann Arbor Science, Fontaine III TD, Bartell SM (eds). MI: Ann Arbor; 29-42.

West DC, Walters A, Gephard S, Post DM. 2010. Nutrient loading by anadromous alewife (Alosa pseudoharengus): contemporary patterns and predictions for restoration efforts. Canadian Journal of Fisheries and Aquatic Sciences 67: 1211-1220.

Williams BK, Szaro RC, Shapiro DC. 2009. Adaptive Management: The U.S. Department of the Interior Technical Guide. Adaptive Management Working Group, U.S. Department of the Interior: Washington, DC.
Winston MR, Taylor CM, Pigg J. 1991. Upstream extirpation of four minnow species due to the damming of a prairie stream. Transactions of the American Fisheries Society 120: 98-10.

Wipfli MS, Hudson J, Caoutte J. 1998. Influence of salmon carcasses on stream productivity: response of biofilm and benthic macroinvertebrates in southeastern Alaska, U.S.A. Canadian Journal of Fisheries and Aquatic Sciences 55: 1503-1511.

Wipfli MS, Hudson JP, Caoutte JP, Chaloner DT. 2003. Marine subsidies in freshwater ecosystems: salmon carcasses increase the growth rates of stream-resident salmonids. Transactions of the American Fisheries Society 132: $371-381$

Zar JH. 1999. Biostatistical Analysis. Prentice Hall: Upper Sadle River, NJ.

Zippin C. 1958. The removal method of population estimation. Journal of Wildlife Management 22: 82-90. 